\title{
Problems Following the Education of Roma Children in Their Free Movement and Their Attempts for Asylum
}

\author{
Msc. Alketa Bulku \\ Vice presdent at "Bajram Curri" middle school, Tirana, Albania
}

\begin{abstract}
Immigration is a growing phenomenon in the recent years with its characteristics on the social groups which are mainly involved and with its impact on the educational level of children also. The life of Roma children is associated with a lot of economic and social problems. They often move inside or outside the country for a more normal life. Frequent changes have their own psycho-social impact on children, as the most sensitive category of the society. They often suffer the long-term consequences which influence the progress of their education and future. Multicultural education and inclusive education are considered to be a good opportunity for marginalised groups offering equal education opportunities in the destination country the same as in their native country, but still they come across some difficulties. This is a qualitative research which aims at giving an analysis about the impact of immigration on the multicultural education and on the inclusion of children within the education system. What happens to these children once in the destination countries and how do they adapt their old experience? What is the impact of this transition on their emotions? The case study was performed through the: theoretical study of the phenomenon, monitoring, students, parents, educators and focus groups' interviews. This study is focused on the primary and low secondary school students. This study introduces some evidence provided by children, educators and parents, proving that returning back to your home country does only enrich their life experience. It does not have a clear positive effect on their education and inclusion to the education process.
\end{abstract}

Keywords: Education, Inclusion, Multicultural Inclusion, Asylum, economic - social difficulty.

\section{Introduction}

Problems following the education of Roma children in their free movement

Globalisation, economic problems and disputes are some of the reasons causing free or obliged movement of different social cultural groups towards more developed countries. They are obliged to seek for better living conditions and they also have to live with the variety of problems related to the cultural characteristics of the nation that they represent and of the country that they come from. Usually the movement takes place from developing countries to already developed or economically consolidated countries. Immigration is a growing phenomenon in the recent years with its characteristics on the social groups which are mainly involved and with its impact on the educational level of children also.

Educational experiences of refugee children in the developed countries, for example in the United States, are from the most marginalised educational groups internationally. Actually, more than half of the 57 million out-of-school children globally live in conflict-affected environment (UNESCO, 2013).

Often the actual kind of knowledge migrant children possess is not of an academic type and as such cannot be measured by the available standardized assessment tools. (Adams \& Kirova, 2005, p. 8). This can result in teachers giving priority to socially sensitive teaching practices, but teachers may also feel less competent to provide the adequate level of content to the newcomer children, and to facilitate their learning. The lack of appropriate curriculum (materials) and sound information about the child's previous educational experiences, as well as poor assessment of general knowledge and skills, can pose challenges to teachers' daily life in a classroom with these children (Educational International, 2010). 
While parents try to improve the quality of their children's lives, they fail to think of their education. Despite the multicultural profits and life experience gained, they risk a permanent disengagement from school. Children face several challenges once in the new country, such as, facing the unknown, social-emotional adaptation, cultural adaptation, extreme difficulties which their families go through, etc. Beside the tradition of the destination country, becoming part of a new education system usually it is based on two strategies, the inclusive and multicultural education, which the last two years are globally considered to be priorities.

\section{Theoretical point of view on the inclusive education and multicultural education}

Inclusive education and multicultural education are education strategies which aim the inclusion and qualitative education of vulnerable and marginalised groups in both the origin and destination countries. Inclusion means being offered equal education opportunities and multicultural education means to give support and show respect for the culture of the country from where the children come.

Banks (1996) defined multicultural education as "a field of study and an emerging discipline whose major aim is to create equal opportunities for students from diverse racial, ethnic, social and cultural groups."(Banks, 1996, p. 46). Nieto (2004)views multicultural education as a process that requires not only challenging issues of difference and diversity, but also those of power and privilege. In other words, when inequitable structures, policies and practices of schools exist, they must be confronted.(Nieto S. , 2004).

Nieto and Bode (2008) expand upon this definition to include seven characteristics of multicultural education. First, multicultural education is antiracist. ( Nieto \& Bode, 2008)

First, multicultural education is antiracist.

Second, it is basic, meaning multicultural education should be considered as important as reading, writing, and math. Thirdly, multicultural education is critical for all students, not just for students of colour, or those who are considered disadvantaged. Fourth multicultural education is pervasive. It is embedded in all aspects of school life, environment, lessons, and relationships among teachers, students, and the larger school community. Fifth, multicultural education promotes social justice. Sixth, multicultural education is an ongoing, complex process that is never fully complete. Last, multicultural education is critical pedagogy based on experiences, knowledge, and viewpoints of the learners and the teachers.

Manning and Baruth (2009) suggest multicultural education is both a concept and process, designed to "teach learners to recognize, accept, and appreciate differences in culture, ethnicity, social class, sexual orientation, religion, special needs and gender"(Manning \& Baruth, 2004, p. 5). In addition, they believe multicultural education should instill a sense of responsibility and a commitment toward the democratic tenants of justice, equality and democracy. Bennett's (2011) writes, "Multicultural education is a complex approach to teaching and learning that includes the movement toward equity in schools and classrooms, the transformation of the curriculum, the process of becoming multiculturally competent, and the commitment to address societal injustices"(Bennett, 2011). Regardless of minor nuances in these descriptions, educators bear the responsibility for changing school culture to reflect the values of multiculturalism(Dimmock \& Walker, 2005).

Inclusive education is an educational strategy aiming the effective inclusion of children in educational activities. Inclusion and integration represent two concepts being so close but far from education.

It is important to make the difference between these two concepts. Inclusion represents a wider concept than integration. Even though integration aims the inclusion of special needs students within the education system, still it is different from inclusion. Different authors (Soder, 1991; Jordan and Powell, 1994; Major, PiljandHegarty,1997) stated that "integration comes after exclusion, as a way to avoid it. Integration can result in adapting the scholar programme to the special needs of students, but that is not enough for their inclusion within education. In the worst case, integration leads only to physical presence of children with special needs within the general schools or to a new version of the scholar programme."

Inclusion means much more that physical presence. "In order to provide inclusive education, various levels of politics and thoughts are needed as it is not only a school concern. It goes beyond connected to the life of children beyond school, to their family and community" (Stangvik, 1997). "Inclusion does not mean only to arrange school environment, but reforming 
the school"(Pijl, Meijer, \& Hegarty, 1997). Reformation means changes in the mentality of the policymakers and professionals of education. Traditional mentality in favour of the education system shall be open for changes influenced by the contemporary paradigm in education and it shall offer solutions for the children's advantage.(Pijl, Meijer, \& Hegarty, 1997, p. 151)

\section{Education in Albania and marginalised groups}

Albania is undergoing an extended economic, political and social transition. Its education system is being reformed due to the need of changes under the influence of globalizing factors. From time to time laws and strategies have been created in favour of thereformation of school policie supporting the multicultural and inclusive education. The first concerning issue seems to be about what's written and what is being put into practice within the education institutions. The implementation of education reform in Albania leads to an education system that includes diversity of students and that adapts education to this diversity. In general, the education environment is characterised by the mentality "one-size-fits-all" and the concept of inclusive education is based on equal teaching for all students, despite their profiles, social background, skills and personal style and without following them individually" (Sultana, 2006). Various researches on the education field have shown that the education reform goes through three levels: the teacher's attitude against students with special needs, adapting the curricula and factors outside the school. The second concerning issue is about how trained and qualified is the pedagogical staff in order to work with those students part of that contingent that needs inclusive education. Inclusive education opposes the avoidance and oppressive values against people and groups in need. These values consider these people as weak due to their problems and negate them as humans.(Armstrong, 2003). In the form of inclusive education, multicultural education interferes as an effective approach. Reducing prejudice and being socially fair, are key standards which need to be empowered and extended within the education system. It presents the role of school in the development of the key attitudes and values to a democratic society. It appreciates the cultural differences and affirms the pluralism reflected by the students, their community and the teacher. It challenges all types of discrimination at school and within the society through promoting the democratic principles of social rights(Sultana, 2006). But still education is a weak point for certain social groups, especially for the Roma people. Marginalisation is the cause to partial inclusion and integration. The Roma inclusion decade 2005-2015, which is the most absolute initiative for the improvement of their life, recognizes education as the key to their social integration. Through this research we are trying to provide a qualitative and measurable perspective of the Roma children education in Albania. Over than $90 \%$ of Roma children do not have a studying place at home. About $70 \%$ of them state that their parents are not able to offer them their help when studying. About $90 \%$ of children state that they do not follow any additional courses on those subjects they might face difficulties. The quality of education received by the Roma children is quite more reduced than that of others(Pasha, 2012).Inclusion and the inclusive strategy are considered by the law on eduation, still no achievements are accomplished.

Albania lacks the full and proper data on the level of education of Roma children, especially for those from official census. Meanwhile, contradicory data come from administrative resources, from various surveys, official estimates or nongovernmental societies. Even the results from Census 2011 did not provide real figures. A lot of debate and discussions came from the side of diferent societies and organizations interested on this target group. There are various reasons why we lack the correct figures. The Roma people live in the outlying districts, in remote not proparly urbanised areas. There should be a clear record taken from the responsible people on the lack of roads and buildings fearing the stigmatization and misuse of the information for discrimination purposes or diesbelieving the state or the scepticism against the profits received from participating in the census;(INSTAT, 2011)

Meanwhile, it is generally known that school enrolment and attendance and the quality of education of the Roma children is very low, school dropouts rates are high and a small group of Roma children graduate in elementary school, even less graduate in high school or university. They say that the Roma children experience various forms of prejudice, discrimination and segregation.

The reasons why the Roma children do not regularly attend school or drop out school are: unregistered births, immigration, commitment to work or helping out their parents who work, lack of knowledge of the Albanian language and unsatisfying assessment at school, being embarrassed to restart school after several dropouts, the need to protect girls once they are teenagers, low educational support from their parents, goods poverty, racism/discrimination. 


\subsection{Social, economic and cultural characteristics of the Roma community related to education}

The Roma and other migrating communities make the biggest minority group in Europe. They observed that in the European Union countries discrimination and other abuses of the human rights against the Roma and other migrating people have been deteriorating and no European government can pretend to be successful in defending the human rights for these minorities which urged the development of an inclusive report on the situation of the Roma and migrating communities in Europe.(UNDP , 2006)

Estimates show that the Roma population in Albania varies from $80.000-120.000$. They are mainly located in the suburb of the cities. They have mainly their identity and conserve their language. The rate of unemployment and illiteracy is four times higher compared to the majority of the population(UNDP , 2006). Social exclusion is viewed as the main cause of their poverty. Governmental policies for the Roma community are known as Ethno-linguistic and not as a national minority due to the lacking a motherland. Yet government says that rights deriving from the Framework Convention on National Minorities are applicable to the Roma people also.

There is a special act related to the policies of education of the Roma children (OSCE, 2003). Even though, many positive attempts referring to school reconstruction or new classes available in the Roma community areas, referring to teachers' trainings and free books dispatching, education strategy objectives have been partially achieved. Although there are specific plans for the implementation of this strategy, the government has not provided the necessary manpower, institutional and financial resources for the implementation of relevant monitoring and evaluating bodies. The ministry of Education and Sports has undertaken the initiative of "second chance" for the education of the Roma children, which represents the most important step towards their educational and social integration. The current strategy for the Roma has not addressed the problem of racism segregation that they do actually experience at school. The objectives of the Roma strategy have not addressed the influence of their family as the most important aspect of education. Education provided to the Roma children does not take into consideration the special sociology of the Roma as a social group.(FRA, 2014, p. 13). All these special and important issues of concern have direct impact on their studying progress. The vicious circle leads only to poverty which can be avoided through giving up school.

\section{The methodology of study}

The case study has been achieved through: theoretical study of the phenomenon, research on documentation, interviews with students, educators, school directors and focus groups of parents.

The qualitative study has been performed in a school in the outlined district of Tirana where $35 \%$ of its students are Roma students and $90 \%$ from those who have been seeking asylum are Roma students. Children who together with their families lived in destination countries were included in the study. The theoretical study of the phenomenon was based on the contemporary literature in order to have a study with multiple points of view.

The research has been mainly focused on the data provided by schools. These documents reflect the attendance and progress of children in the countries where their families were seeking asylum. Only those attending German schools have submitted documents from corresponding schools. Students studying in other countries were not provided with the requested documents.

Through the interviews with students we were introduced to the long way towards asylum, their emotional experiences and description of schools that they have attended in the destination countries.

The interviews with teachers were performed in order to make an analysis on the situation of the children after their return from relevant schools.

The interviews with school directors were performed to have information on the behaviour towards them once they are returned in their old classrooms and to have a deeper knowledge on the problems which follow the phenomenon.

Focus groups were created in order to have an answer why they are always leaving to other countries, regardless of the refusal of their request for asylum, in order to confront their thoughts and understand in depth their lives challenges andtheir mentality. 
Which are the factors that lead the Roma community in Albania to seek asylum

Poverty is the major factor that draws them to seek asylum. Albania lacks the official statistics but subsequent studies have been made from various organizations offering their help to this community as per humanitarian and study purposes also.

The average income per head for Roma people in Albania, in the first half of the last decade has been estimated less than one third of those non-Roma people and over $80 \%$ of them live under the living level of $14 \%$.

On the other hand, the regional study of 2011 for the Roma gives the average 37\% live under the estimated indigence rate for the Roma population or more than the duplicated estimated indigence for the non-Roma population who lives near to the Roma areas.

The study results published by the UNDP in 2006 show the Roma unemployment level is almost 3 times higher than the non-Roma population as a result of the combined poor teaching and discrimination. According to the regional study of the Roma in 20122, the quality of their living conditions is problematic. $36 \%$ out of the Roma houses, $61 \%$ from them do not have a toilet. A considerable number of Roma houses (30\%) do not have direct access to consumable water.(OSCE, 2013)

Two years later, another study writes: generally the major problems for the Roma community have economic nature related to the possibility to afford a decent life, like, unemployment, lack of food, lack of living conditions etc. The Roma seems to be quite pessimistic about their near future finance. Only $15 \%$ of them think that their economic condition will be better in 2013 than in 2012. The remaining think that it will become worse (33\%), or that it will continue to be the same (24\%), or that they do not know how to answer (29\%).

According to their statements, their family income can only help them survive and in the majority of cases they can hardly survive. Incomes from informal activities, like collecting and selling recycled materials is the main way $40 \%$ to earn their living. If we come to include those who declare to earn their living from employment in the informal private sector (10\%), and those declaring occasional employment as the main way of earning a living (day based work, $11 \%$ ), the result is $61 \%$ of Roma families earn their living through working in informal sectors.

The only chance of doing a state paid job is for some family heads working in the greenery or cleaning service, etc.

The Roma community is unsatisfied even from the labour office (about $74 \%$ ). They state that from those declared as unemployed; only $29 \%$ are registered in the labour office while $71 \%$ of the unemployed Roma people who could have the support of the labour office services are not able to register.

The Roma state several causes for their unemployment. They are mainly related to the lack of job opportunities generally in Albania, ethnicity, their low educational and professional level. So, the data show that $81 \%$ of the Roma people do not have a profession, $9 \%$ have low demand professions and only $6 \%$ have inn-demand jobs.

Living conditions for the Roma are too difficult. According to the study, $35 \%$ of Roma families live in no larger than $40 \mathrm{~m}^{2}$ areas and that $31 \%$ of their houses are used by two or more families. $18 \%$ of Roma families live in huts and shacks, in very difficult conditions and there is no opportunity to turn them into legal properties, while $50 \%$ of them declare living in old houses.

Nearly one in three Roma people say "unemployment" is their major problem in their ordinary life. Generally, the real problem of this community is their financial status and challenge of affording a decent life...(Pasha, 2012, p. 14)

Among the most common works are: second hand goods trade, collecting recycling materials, plastic and paper. In order to collect all these materials they wander through garbage bins near to the urban areas or at the garbage patches. We have to stress that different aged children are involved in these works.

Another common phenomenon is their exploitation as street beggars. Cases when they are monitored by mentors are even more serious, working under pressure to collect certain amounts of money. Very often TV investigative programmes have shown facts that these children are victims of human trafficking. Often, Roma families are big families which consist of numerous members and the elders take decisions on behalf of the young members, usually affecting their education in 
favour of early marriages or keeping girls at home. During a session from the interviews of focus groups with parents, they say: "although we have been through a lot of difficulties such as our journey to Germany and moving from one camp to the other while seeking for asylum, after being unsuccessful and returning back here, we will keep trying. We cannot have a proper job here; we collect various materials, refrigerators, washing machines whenever we find any. Our earnings per day depend on the goods we collect. Women are unemployed while our little kids need care. We do not have assistance and if we go there, for sure we will be provided financial support and shelter. Besides, we can do some works of community and maintenance service etc. Our major problem is language, as it prevents us from getting a job but we hope our children learn."

Another parent says that they sell second hand goods but this is not being allowed anymore as the police are asking for business license and permits and in contrary they take hold of all goods. "But we don't have licenses for this! I won't apply for one anyway! Do we earn enough money to apply for one?"

\section{Free movement and immigration impact on education and confrontation of the Roma children to new reality}

Being a group in need and always affected by subsequent changes and traditionally moving from one country to another, they often experience new things. A lot of refugee children experience dropouts from school or limited approach to education.

Based on relevant policies in the destination countries, refugee children are included within the education system and they can attend language classes according to their age. A lot of difficulties related to adaption to the new educational level are witnessed, mainly related to their learning progress in their homeland.

The educational experience of the refugee children in the First Asylum countries seem to be far from the objectives of the UNCHR. These global education models for the refugee children in the First Asylum countries have had their impact on their education after resettling to the destination countries.

Refugee children might manifest some learning difficulties, due to school dropouts, not because they are lacking skills. Learning gaps can be minor (after dropping out school for some weeks only) or big (years without attending school). Education is often sporadic after they are settled in the new country, which can influence their families' attitudes. Based on the past experience, teachers can recognize the parents or children's hesitation to invest time on school and relevant relationship. Refugee children are usually exposed to multiple language learning which can lead to language confusion and limited opportunities to master academic language.

Careful attention is necessary in order to identify the learning needs based on their academic experience, compared to the born capacities to learn. There are various factors that might prevent refugees' enrolment at school, including their living in acute needs; conflict, legal restrictions according to enrolment and frequent displacement in the first asylum countries, and also the fear of getting exposed to migration applications or other authorities.

Refugee children usually face language barriers. They can have obstacles with lessons that have to be learnt in a different language from their own, or in case they have to take lessons in a limited resource environment in order to support language learning. Refugees in the same class can speak different languages which need various interpretations; they can slow down or interrupt the teaching process. They are usually exposed to many languages which prevent them from mastering one of them.(Bourgonje, 2010)

Children leaving Albania, face two language challenges. First, in their country the lesson is not held in the Roma language. They speak their language just in the family setting and when they attend Albanian schools, they start to learn Albanian language as their first foreign language, spoken and written. In the asylum countries they are introduced to a new unknown language. So, in a very short time, they are exposed to three different languages. If we add academic barriers to this, children then will feel not ready to attend school.

\section{Education in the destination countries}

Problems with education in the destination countries have been treated by various researcher in the recent years. International data show the growing rates of migration all over the world and more than the half of refugees consists of 
children. Migration has several educational impacts(Bourgonje, 2010). It is important to highlight that there is no difference between educational problems and needs. Children of refugee and immigrants seeking asylum has turned into a global concern for educators. Education systems face the need to answer to the current tendencies of migration and to the demographic changes of students in an adequate manner.

Migrant education is high on the policy agenda in many OECD countries. Growth of the ethnic and cultural diversity provides new opportunities and challenges within the education systems. While, focusing on outcomes for these children and reviewing education policies at the international level, has rarely been done. In 2008, The OECD Thematic Review on Migrant Education has started a project in support of developing practices by ensuring a deep analysis on the approach to immigrants' education(OECD, 2008).

There is a low and unequal education provided to refugees. As a result, even those refugees who have displaced their children from the first asylum countries might have lower skills and knowledge than their peers.

Another problem for Roma children from Albania is that they leave without getting any documents from schools. How do they integrate in their new classrooms?

The focus group with parents said: "school enrolment was arranged by the social centre that used to cover: monthly payment, health problems, school, so, you could turn to them for any issue of concern. Enrolment in classes or language courses was done according to age. You could receive language classes in common classrooms for three days and in your classroom for two days. They were integrated at school but depending on the interest and possibility shown by their parents. Parents' interest was relative from one family to the other. The most important thing was learning the new language, and this was worth for us parents as well."

The Roma students who had attended school came from several European countries, such as: Italy, France and Germany. Only a few students had attended classes regularly according to their age. Only those students coming from German schools were provided with the corresponding documentation. Picture 1, shows one photo of the documentation provided to student A. R. by the school she used to go to.

Picture 1

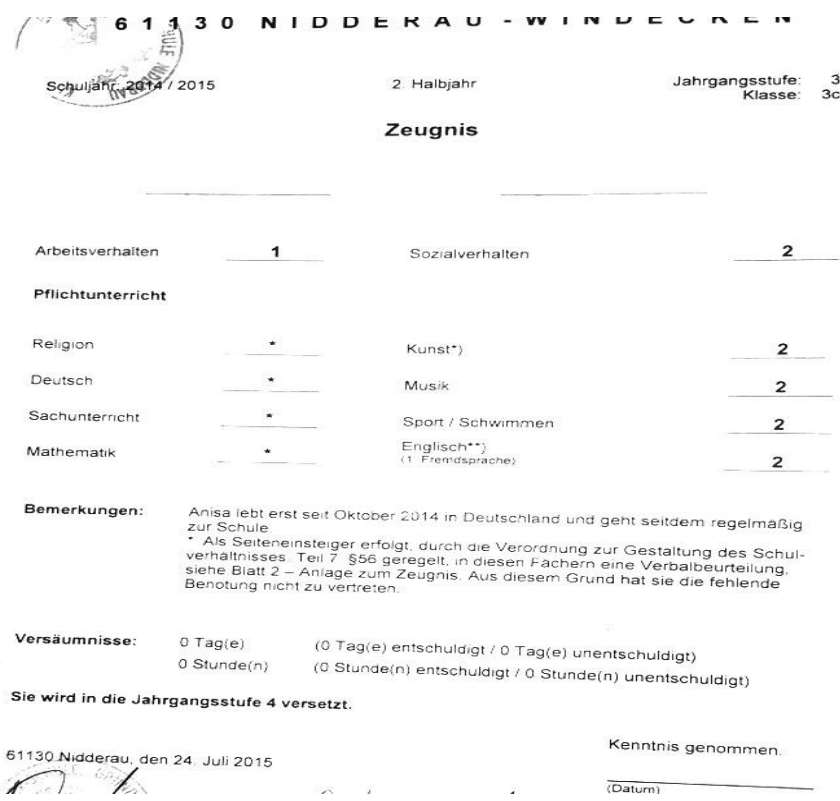

In the document it is said: A.R. lives in Germany from the last October and since that time she attended school regularly. 
In German language she masters reading. She is confident when reading already conducted texts but her reading skills in new texts are vulnerable. Her writing is recognizable. A. R. is able to use capital or lower case letters in her exercises. She has done progress in mathematics. She is willing to work according to her abilities and enjoys her achievements. A. R. is interested in ethics and her inclusion varies according to her language skills during the class. She is very active during school activities. She learns quickly and sheis highly motivated. Her vocabulary has improved and she is able to discuss with teachers and peers.

Picture 2

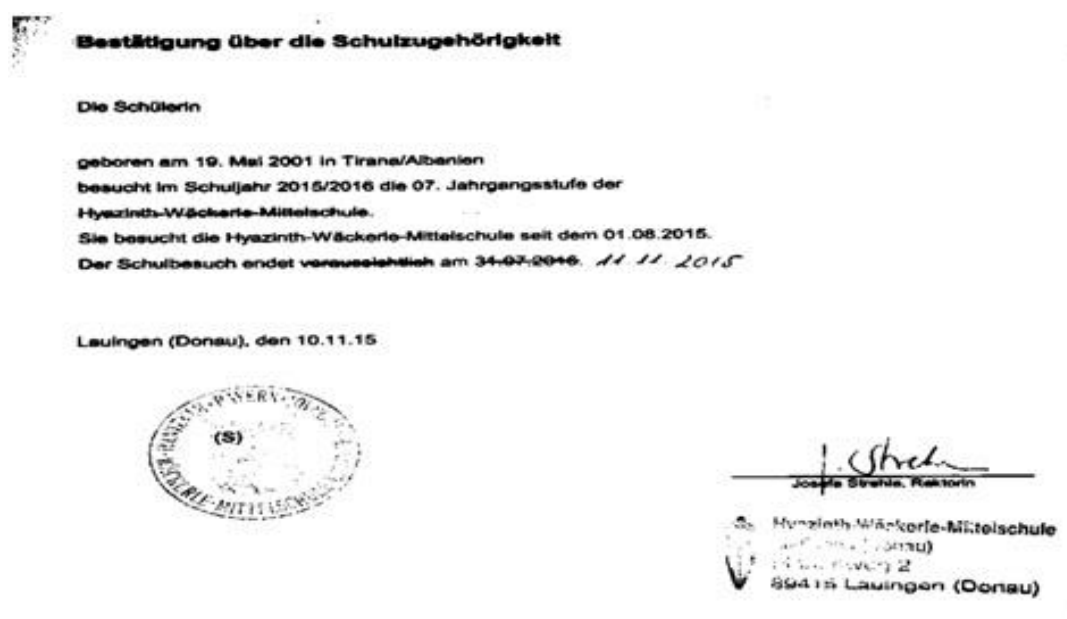

Certificate of Attendance. She was born on 19 May in Tirana and she is attending the academic year 2015-2016, seventh grade. She attended school from 01.08.2015 to 11.11 .2015

Picture 3 is a photo of the document from student J. XH.

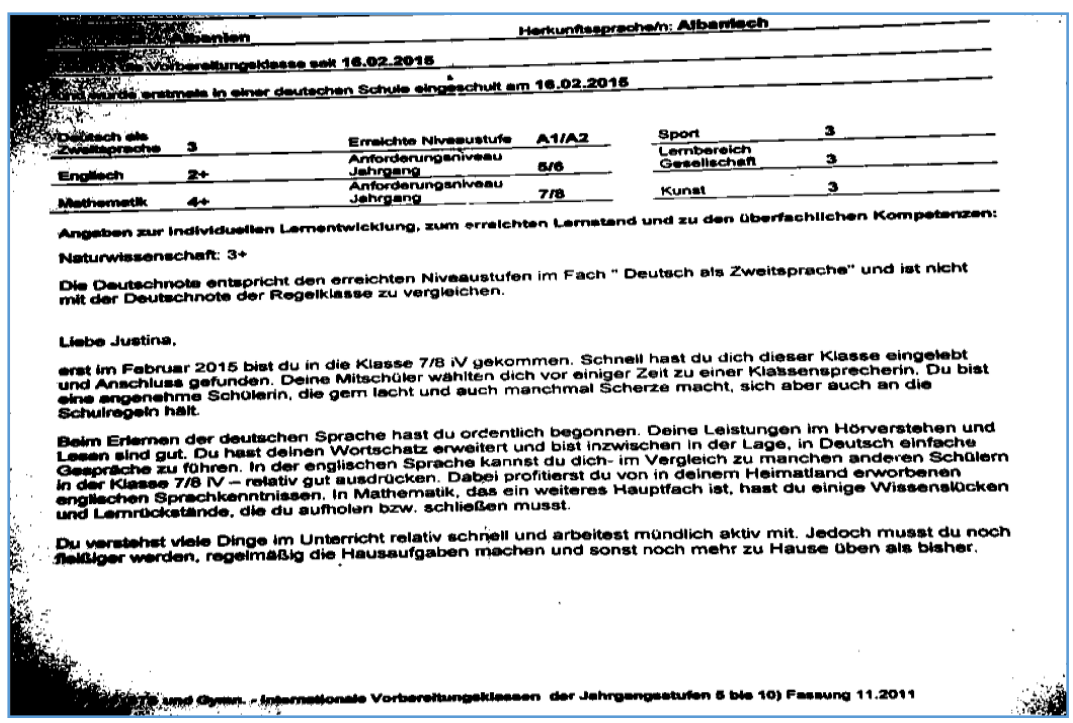


In the document it is said: for student j. XH.,German language assessment shows the achieved level in German language and it is not the equivalent to the normal classes evaluation. Dear J. XH. you came at school in February 2015 and you integrated within a short time. You are a very good student, always smiling; you make jokes but always respecting the rules. You are always learning and your listening and reading skills are very good. Your vocabulary is improved and you are able to make simple discussions in German language. As compared to other students, you can express yourself very good in English language. There are a few deficiencies in mathematics which you need to improve, as it is one of the key subjects. You can understand things relatively fast, and your verbal communication is active. Even though, you have to show your earnest effort to regularly do your homework and get more exercises done at home.

\section{Observations performed within the school environment after returning back at their homelands}

In some countries, the Roma asylum seekers have been provided kind of temporary defence, which prevented them from getting the status of the resident even not progressive exhibition of their rights. Repetition of the disposition of a shortly "tolerated" status has prevented thousands of Roma people to come and integrate within the new societies. The right to asylum has been recognized by the United Nations Convention relating to the Status of Refugees (1951) for all refugees without discrimination. The Roma asylum seekers and displaced persons have to be treated the same as the non-Roma asylum seekers or displaced people. Many European countries have performed banishing practices for the Roma. The document from the Committee of Ministers of the Council of Europe, 20 guidelines on forced return provides the standards on defence procedures which the state members should respect when undertaking forced return. The guidelines stress that group banishing of expats is forbidden(UNDP , 2006).

After they return back to Albania, schools adapt the current laws, that means putting the child at the same classes they were attending before leaving. The school director says: "based on the guideline for students returned from immigration date, 10.11.2015, students returning from immigration, especially those coming back from Germany, and from other countries also, get enrolled according to their age, after doing an exam testing the level of their knowledge, or converting the results from the documentation provided by the previous school. Usually there is no documentation provided, or it does not fit with our system. So, they attend classes just a limited number of subjects, such as language, mathematics and a few sciences, but they have proper attendance at school and regular learning. There are 19 students who returned from immigration and started to attend the same grade that they were previously attending. Their performance was poor even though they keep attending school regularly, but still improvement is difficult. The documentation provided by these students, they evaluate the language knowledge as a second language, basic knowledge which makes not possible for them the understanding of the information but evaluation is given to their commitment and willingness to learn. There are at least 11 students who have decided abandon school as they think they will not make it and they do not accept to follow lower grades. Separation from school have many consequences in children, they aim at dropping out school, especially if they are in the higher grades."

After going back to school, student L. 13 years old describes her return as follows: "we left our country because my mother was unemployed, my father sells second hand clothes in the trade market, but we cannot afford a living as there are 6 members in my family. We left on July 2015 , traveled by bus, ferry, and then by bus again, changing a country every 3 hours. We stayed for 1 month in camps. We spent 15 months abroad. We couldn't attend a lot of courses as we were moving quite often. If we stayed more we could go to school. As we were told the school was a very good one. We couldn't go to school, so we attended just a few courses instead. I was happy to come back because I missed my friends and my school."

Student I, $6^{\text {th }}$ grade, says that: "we could learn some things, some German, some English, we did some sports like swimming and other sports, we sometimes went to excursions or camping. I can't say it was not good, but I like it more here. My mother, my father and my sisters and brothers went back to Germany again, but I didn't want to. I preferred to stay here with my grandparents because I missed them, I missed my neighbourhood, my friends and my school. Despite this, I feel better with my old friends. When I first came here, I knew just a little Albanian as we used to speak Roma language at home, then I got used to it, while I had to learn German and English there. It was difficult for me to learn two additional languages and even though I tried, I could hardly find the words to speak."

Student $E, 5^{\text {th }}$ grade, after her return back she says, "We were so happy to come back, especially me and my sisters as our home and friends are here." 
$\mathrm{H}, 5^{\text {th }}$ grade, describes her journey back like this: "We used to go to school there. A kind of a supervisor, used to come and enrol us in different courses. There were about 20 students from different nationalities and age in these classes, but we didn't feel bad about it. I liked the way how we used to learn English and my performance was good. There were TVs and the blackboards were similar to TVs. We used to do mathematics and we it was clear those coming from Afghanistan were very good in mathematics. I like it more there, even school was better. I started being friends with an Italian girl. I would like to go back again."

A, 15 years old, says: "I stayed at school for 9 months. There were 40 students in the classroom. There was food service at school. I had a school card and I used to go there regularly. I started to like school after learning German. I will regularly attend school here also, even though I started being absent a few times before leaving Germany because I had to help my family at the trade market sometimes."

Student J, 15 years old, reveals her experience: "we spent almost 2 years there. I went there with my family and the cause was financial situation for sure. We don't earn a lot here; my parents do not have a permanent job. I started to go to school there, so did my sisters. There is not much similarity between schools here and there. I don't know, but school there is less busy and more practical than here. We will try to go back there again. Meanwhile I will finish elementary school here."

In their interviews, teachers describe some of their students who returned back here.

The second grade teacher says: "when I ask him, "what did you learn? Which were your favorite subjects there?" - He looked at me amazed. He tells me that they used to play with friends and teachers in the classroom and in the yard also." The teacher describes her work like this: "We aim to provide teaching techniques based on games, not only because of the physical conditions of school, but the program itself prevents us from free activities. We try to exercise children continuously because our job is also measured by testing students' achievements in the key subjects: mathematics and language."

The fifth grade teacher describes the return of her student as follows: "when he first came back, he was kind of more driven back, as he was not as troublesome as the others, but now he is similar to them. I noticed that children would notice the change also."

The seventh grade teacher, she describes her 3 students: "there are many gaps in their learning, maybe because of the big distraction or loose of interest. I often talk to them in order to recognize the causes, but there can be too many; comparison to the previous environment, lose faith in parents, impossibility to earn back the lost time etc.In the beginning I thought they would be more mature and take it more seriously, but I see they are putting less effort than before."

\section{Conclusions}

The qualitative research brings light on the immigration phenomenon of the Roma population from Albania to the developed countries of the region for a better living. The main reason of leaving the country is poverty and lack of the basic conditions of living. Because of poverty, their children do not attend school regularly as they are being exploited to work since an early age. Frequent displacing leads to even longer separation from school. Seeking for asylum offers the opportunity to leave in other countries for some months. Depending on the destination country policies, children attend courses or classes according to their age. Their education in these countries faces language difficulties and academic formation such as maladjustment. In the documentation provided by schools the go to in the destination countries, it is said that their knowledge is not comparable to those students going to normal classes. Destination countries institutions evaluate the students' attitude and social relationship more than the acquired knowledge. Asylum rejection sends them back to the origin country where they have to face the same problems as before, even worse than before. In this case, families will be looking for another chance of immigrating and again children will have to leave school. In conclusion of the study, we can say that frequent displacement of the Roma families in search of better living conditions do only enrich their experiences without providing a clear positive impact on the multicultural education or inclusive education.

\section{Bibliography}

[1] Nieto, S., \& Bode, P. (2008). Affirming Diversity: The Sociopolitical Context of Multicultural Education (5th ed.). Boston, MA: Allyn and Bacon. 
[2] Adams, L. D., \& Kirova, A. (2005). Examining culturally appropriate assessment practices in early childhood development (ECD) programs. Global Migration and Education. Schools, Children, a, and Families. Lawrence Erlbaum Associates, Mahwah, p. New Jersey \& London.

[3] Armstrong, F. (2003). Difference, discourse and democracy: the making and breaking of policy in the market place. International Journal of Inclusive Education.

[4] Banks, J. A. (1996). Multicultural Education, Transformative Knowledge, and Action: Historical and Contemporary Perspectives. New York: Teachers College Press.

[5] Bennett, C. I. (2011). Comprehensive multicultural education theory and practice. Boston: Allyn \& Bacon.

[6] Bourgonje, P. (2010). Education for refugee and asylum seeking children in OECD countries. Amsterdam.

[7] Dimmock, C., \& Walker, A. (2005). Educational leadership: Culture and diversity. . London: Sage.

[8] Educational International. (2010). Educational International. p. De Jonge / De Smedt.

[9] FRA. (2014). Education: the situation of Roma in 11 EU Member States. Vienna, Austria: European Union Agency for Fundamental Rights. Retrieved from http://fra.europa.eu/sites/default/files/fra-2014_romasurvey_education_tk0113748enc.pdf

[10] INSTAT. (2011). Profili i Romëve dhe Egjiptianëve. Tirane: Census, INSTAT.

[11] Manning, M., \& Baruth, L. (2004). Multicultural education of children and adolescents. (4th ed.). Boston: Pearson.

[12] Nieto, S. (2004). Affirming diversity: The sociopolitical context of multicultural education. . New York: Longman.

[13] OECD. (2008). Migration \& mobility: challenges and opportunities for EU education systems. Green Paper. Retrieved from http://www.oecd.org/document/17/0,3343,en_2649_39263294_39887569_1_1_1_1,00.html

[14] OSCE. (2003). National Strategy for improving Roma living Conditions, No 633. Tiranë: OSCE.

[15] OSCE. (2013). Raporti rajonal mbi antidiskriminimin dhe pjesëmarrjen e romëve në vendimmarrjen lokale : praktikat më të mira pèr integrimin e romëve. Tiranë: OSCE/ODIHR.

[16] Pasha, A. (2012). Raporti per romet. Tiranë.

[17] Pijl, S. J., Meijer, C., \& Hegarty, S. (1997). Inclusive Education: A Global Agenda. London and New York.

[18] Stangvik, G. (1997). Beyond schooling; integration in a policy perceptive. London: Routledge.

[19] Sultana, R. G. (2006). Facing the hidden drop-out challenge in Albania. Evaluation report of hidden drop-out project piloted in 2001-2005'. . Tirane: UNICEF.

[20] UNDP . (2006). Social Vulnerability of Roma in Albania. UNDP .

[21] UNESCO. (2013). Fëmijët ende janë duke luftuar për të shkuar në shkollë. Paris: UNESCO.

[22] Banks, J. A. (2006). Diversiteti kulturor dhe Edukimi: Fondacione, Kurrikula dhe Mësimdhënia.

[23] Brooks, J., \& Thompson, E. (2005). Social justice in the classroom. Educational Leadership.

[24] Camicia, S. P. (2007). Deliberating immigration policy: Locating instructional materials within global and multicultural perspectives. Theory and Research in Social Education, 35(1), 96-111.).

[25] Florian, L., \& Rouse, M. (2009). The inclusive practice project in Scotland: Teacher education for inclusive education. Teaching and Teacher Education 25(4), 594-601.

[26] Fondacioni Shoqëria e hapur për Shqipërinë. (2012). Dekada e romeve dhe situata e romeve ne Shqiperi. Tirane.

[27] Gedeshi, I. (2010). Global Crisis and Migration: monitoring a key transmission channel to the Albanian economy". Tirana: UNDP \& IOM.

[28] Grant, C., Sleeter, C. (2008). Turning on Learning: Five Approaches for Multicultural Teaching Plans for Race, Class, Gender and Disability. New York 
[29] INSTAT. (2011). Profili i Romeve dhe Egjiptianeve. Tirane: CENSUS. Retrieved from http://www.al.undp.org/content/dam/albania/docs/Census\%202011\%20Profili\%20i\%20Romeve\%20dhe\%20Egjiptian eve $\% 20$ final.pdf

[30] Janaqi, G. (2013). Llojet e paragjykimeve në zonat migratore të Shqipërisë mes të ardhurve dhe vendasve (Doktoraturë). Tiranë: Universiteti i Tiranës.

[31] Law 69/2012. (2012). On Pre-University Education System in the Republic of Albania. Tirane: Official Journal.

[32] Leeman, Y. M., \& Volman, M. (2001). Inclusive education: recipe book or quest. On diversity in the classroom and educational research. Routledge.

[33] Leeman, Y., \& Ledoux, G. (2003). Preparing teachers for intercultural education. . Teaching Education, 13(3), 279292.

[34] MAS. (2015). Vlerësimi i arritjeve të nxënësve të klases se 3-të dhe të 5-të. Tiranë: MAS. Retrieved from http://www.arsimi.gov.al/files/userfiles/prezantime/Vleresimi_Kombetar_kl_3_dhe_5_final.pdf

[35] MAS. (2016). Raporti - Identifikimi i nevojave për trajnim. Arsimi.gov.al.

[36] MAS. (2016). Raporti Kombëtar i Identifikimit të Nevojave për Trajnimin e Mësuesve dhe Drejtuesve të Shkollave. Ministria e Arsimit dhe Sportit. Retrieved from http://www.arsimi.gov.al/al/newsroom/lajme/raporti-kombetar-iidentifikimit-te-nevojave-per-trajnimin-e-mesuesve-dhe-drejtuesve-te-shkollave

[37] Musai , B., Ikonomi , E., \& Sotirofski, K. (2009). Raporti vendor për Shqipërinë. Bolonjë: SCIENTER dhe Qendra për Politikën Arsimore.

[38] Nieto, S., \& Bode, P. (2008). Affirming Diversity. The Sociopolitical Context of Multicultural Education (5th ed.).

[39] Nikolovska, M. (2008). Human Resource Development, Country Analysis, Albania. Tirane: European Training Foundation .

[40] Noddings, N. (1995). Philosophy of Education .

[41] Shoqëria Civile. (2012). Monitorimi nga Shoqëria Civile i Zbatimit të Strategjisë Kombëtare dhe i Planit të Veprimit në Shqipëri. Tiranë: Decade of Roma Inclusion Secretariat Foundation. Retrieved from https://www.google.al/url?sa=t\&rct=j\&q=\&esrc=s\&source=web\&cd=5\&cad=rja\&uact=8\&ved=0ahUKEwjm6M26q5HM

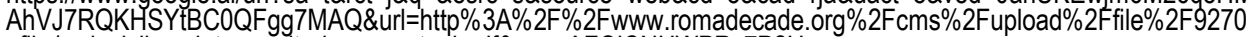
_file1_al_civil-society-monitoring-report_al.pdf\&usg=AFQjCNHWPRc7P2H

[42] Tamo, A., \& Karaj, T. (2007). Raport studimor. Tiranë: UNICEF \& Save the Children.

[43] UNDP. (2011). Dekada e përfshirjes së romëve - Plani kombëtar i veprimit 2010 - 2015. Tirane: UNDP. Retrieved from https://www.google.al/url?sa=t\&rct=j\&q=\&esrc=s\&source=web\&cd=3\&cad=rja\&uact=8\&ved=0ahUKEwi4wfYqZHMAhXEthQKHb-

aBhcQFggvMAI\&url=http\%3A\%2F\%2Fwww.undp.org\%2Fcontent\%2Fdam\%2Falbania\%2Fdocs\%2FDekada\%2520e $\% 2520$ Perfshirjes $\% 2520$ se $\% 2520$ Romeve $\% 2520-\% 2520$ Plani $\% 2520$

\section{Appendix 1}

How competent do you feel on understanding the Roma community - from 1 to 5 meaning, very competent, competent, somehow competent, a few or not at all.

Did you gain confidence after the social justice training - from 1 to 5 meaning, very competent, competent, somehow competent, a few or not at all.

Did you gain an experience from the training on the treatment of the Roma children in the classroom? - from 1 to 5 meaning, very competent, competent, somehow competent, a few or not at all.

Appendix 2

sex $F \quad M$

Age (circle) 25-30 30-35 35-45 45-55

Have you heard of multicultural education yes No

If Yes, please try to write a short description

Does It represent an important element of teaching, or you think it is not suitable for Albania? 
Yes

No

it is not suitable for Albania

Mark with +

According to your opinion, multicultural education has to do with racism, sexism, classism, linguistics, religious

intolerance or xenophobia

Do you think teacher are prejudicial to students?

If Yes, is that relate more to:

Economic background, racial background, sexual orientation, religious belief, Gender belief corresponding ethnicity (Aromanians, Greeks, Macedonians) put numbers from 1 to 6 .

is there any prejudice reflected if the teacher asks the girls to clean and the boys to fill the water?

Yes

No if Yes, what type of prejudice?

is the teacher more familiar to the child of the businessman or the cleaner?

What type of prejudice do we have here?

Do you think it is reasonable to have information on the culture and tradition of your students so the teaching process is more qualitative?

Yes No

Were there any Roma students in your classroom? Yes No

If Yes, did he/she sit In|: the front desk last desk in the middle you do not remember

Can you make the difference between a Roma and an Egyptian? Yes No

If yes, which is the indicator?

Is it important for you to make the difference between them? Yes No

What do you think about his/her development, if there was a Roma student in your classroom?

Good Very good Bad Sufficient Comment

Is it necessary for you to follow any training in order to help you with minimizing your prejudicial attitude towards the students?

$$
\text { Yes No }
$$

Do you think that this is a prejudicial questionnaire?

Yes

No

Semi-structured interviews for parents and teachers

Appendix 3

The questions included within ths semi-structured interview are:

Did you decide on who your teacher will be, or just as it goes by chance?

Which was the selection criteria, age, personal knowledge, being rude or accurate with the children?

Do you think you have to meet the teacher often? 